\title{
MEDIAD
}

ARAŞTIRMA MAKALESI | RESEARCH ARTICLE

Aralık 2021, 4(2), 251-262

Geliş: 08.11.2021 | Kabul: 14.12.2021 | Yayın: 31.12.2021

DOI: $10.47951 /$ mediad.1020796

\section{Eylül Sonrası Valeurs Actuelles ve L'express'de Medeniyetler Çatışması ve İslam Algısı}

\author{
Müșerref YARDIM* \\ Betül KARAKOYUNLU**
}

Öz

Içinde bulunduğumuz dijital çağda pek çok konuda olduğu gibi i̇slam dünyası ile ilgili bilgi de kitle iletişim araçları ile üretilmektedir. Yazılı basın, televizyon, dergi ve gazeteler bir yandan islamofobik üretime katkıda bulunurken diğer yandan İslam ve Müslümanlara yöneltilen nefret söylemlerini meşrulaştırma ve yaygınlaştırma işlevi görmektedir. Batı ana akım medyası bu konuda etkin biçimde kullanılmakta, hayali ya da öteki İslam ve Müslüman inşası artarak sürmektedir. Medeniyetler Çatışması tezi ile temelleri atılan çatışma ortamı, 11 Eylül ikiz Kule Saldırılarının katkısı ile medya için oldukça elverişli bir propaganda zeminine dönüşmüştür. Medeniyetler çatışmasının yanı sıra Aydınlanmanın aklı merkeze alarak kutsala karșı tavır takınması Batı'nın dinle husumetini artırmaktadır. Öte yandan İslam'ın sosyal hayatın her alanını kapsayıcı kodlara sahip olması seküler değerlerle çelişmekte ve özelde İslam'a karşı agresif tutumları ortaya çıkarmaktadır. Bu bağlamda zalim, despot, barbar ve gerici Doğu'nun demokrasi, eșitlik ve hukukun üstünlüğü gibi evrensel değerlere sahip Batı’ya karşı savaş açtığı bir portre çizilmektedir. Özellikle 11 Eylül Saldııları sonrasında atmosfer medyanın İslam ve Müslüman karşıtlığını körüklediği tartışılmazdır. Bu durumun temel nedeni hem Batı'nın işgalci hareketlerini sağlam bir meşruiyet zemininde inşa etmek hem de Batı toplumlarındaki öteki algısını diri tutmak sureti ile Batılı kimliğin inşasını sürdürmektir. Bu çalışmanın amacı Batı ana akım medyasının öteki olarak İslam'ın inşa edilmesindeki rolüne yönelik çıkarsamada bulunmaktır. Bu bağlamda Fransa'da yayın yapan yüksek tirajlı iki derginin kapak seçimleri nitel araştırma tekniklerinden göstergebilimsel analiz yolu ile çözümlenmiştir. Araştırma sonucunda her iki derginin de kullandığı görsellerin, renklerin, dilin ve kelime öbeklerinin amaçlı olarak tasarlandığı tespit edilmiştir. Bu tasarımda Batı ve Doğu, din ve coğrafya bakımından karşı karşıya getirilmekte, iki ayrı medeniyetin çatışması vurgulanmaktadır. Öte yandan göstergelerin ayrıntılı olarak izi sürüldüğünde, Doğu'nun artan popülasyonu karşısında Batı toplumlarının endişe duymasının amaçlandığı ve Hristiyanlığın İslam karşısında giderek zayıflayacağına yönelik kaygı ortamı yaratılmaya çalışııdığı ifade edilebilir.

Anahtar Kelimeler: İslamofobi, Medya, Oryantalizm, 11 Eylül Saldırıları

\section{The Conflict of Civilizations and the Perception of Islam in Valeurs Actuelles and L'Express after 11 September}

\begin{abstract}
In the digital age we live in, information about the Islamic world is produced by mass media, as is the case with many issues. While the print media, television, magazines and newspapers contribute to islamophobic production, on the other hand, It functions to legitimize and spread hate speech against Islam and Muslims. Western mainstream media is used effectively in this regard, and the construction of imaginary or other Islam and Muslims continues. The conflict environment, whose foundations were laid with the Clash of Civilizations thesis, is quite favorable for the media with the contribution of the September 11 Twin Tower Attacks. It has become a propaganda ground. In addition to the clash of civilizations, the Enlightenment was sanctified by centering the mind. Taking a stance against religion increases the hostility of the West to religion. On the other hand, the fact that Islam has codes covering all areas of social life contradicts secular values and reveals aggressive attitudes towards Islam in particular. In this context, the cruel, despotic, barbaric and reactionary East has universal values such as democracy, equality and the rule of law. A portrait is drawn against which he wages war. Especially after the September 11 attacks, the atmosphere media has changed the way of Islam and Muslim. It is indisputable that it fueled opposition. The main reason for this situation is to give a solid legitimacy to the invading movements of the West. It is to continue the construction of the Western identity by building on the ground of the other and keeping the perception of the other in Western societies alive. The aim of this study is to determine the role of Western mainstream media in the construction of Islam. In this context, the cover selections of two high-circulation magazines published in France analyzed using semiotic technique. As a result of the research, it was determined that the images, colors, language and phrases used by both magazines were designed with purpose. In this design, West and East, religion and geography the conflict of two different civilizations is emphasized. On the other hand, it is aimed that Western societies should be worried about the increasing population of the East. According to this idea, Christianity is getting weaker in the face of Islam.
\end{abstract}

Keywords: Islamophobia, Media, Orientalism, September 11 Attacks

ATIF: Yardım, M. ve Karakoyunlu, B. (2021). 11 Eylül sonrası Valeurs Actuelles ve L'express'de Medeniyetler Çatışması ve İslam algısı. Medya ve Din Araştırmaları Dergisi (MEDiAD), 4(2), s. 251-262. 


\section{Giriş}

İslam karşıtlığının kökeni ABD ve Batı Avrupa'da yüzyıllar evveline dayansa da 11 Eylül saldırıları sonrası sistematik bir biçime büründüğü ve gündelik olana sirayet ettiği kabul edilmektedir. İslamofobi gerçek bir korkudan ziyade tasarlanmış, üretilmiş ve rasyonel olmayan bir korkuyu ifade etmektedir. Bu tasarımda bugüne değin ortaya atılan pek çok çatışma fikrinin etkisi bulunmaktadır. Sovyetler Birliğinin tarih sahnesinden çekilmesi ile beraber çift kutuplu dünya düzeni ortadan kalkarken, yıkılan komünist bloğun yerine yeni bir düşman arayışı için fikirler üretilmeye başlamıştır. Bu bağlamda ABD ve Avrupa ülkelerinin mevcudiyetini sürdürebilmesi için komünizm yerine İslam'ı işaret eden fikirler ortaya atılmışır. Samuel Huntington'un (2006) Medeniyetler Çatışması tezi, Batı ile İslam'ı tarihin yeni bloğu yapmayı hedefleyen anlayışa en önemli katkıyı sunan fikirler arasındadır. Gerek Batı'nın yeni bir öteki arayışı gerekse medeniyetler çatışması tezinin bir tezahürü olarak, 1990'lı yıllardan itibaren özellikle Batı ülkelerinde yaşayan Müslümanlar şiddet içeren pek çok ayrımcı tutuma maruz kalmıştır. Özellikle 11 Eylül saldırıları, başta ABD olmak üzere Fransa, Hollanda ve İngiltere gibi Avrupa ülkelerinde İslamofobik eğilimlerin artışında kilit rol oynamıştır. Diğer yandan İslamofobi Müslümanların öteki olarak inşa edilmesinde bir alçı görevi görmüştür. Esasında her toplumun içinde nefret gruplarının var olması kaçınılmazdır. Ancak önemli olan toplumu yönlendiren aktörlerin nefretin yönelimi hakkında nasıl bir duruş sergilediği ile ilgilidir. Bu aktörler içinde medya, kitlelerin dizayn edilmesi için en etkili araçtır. Nitekim medyanın manipüle etme, örtme ya da açığa çıkarma kabiliyeti düşünüldüğünde toplumsal tabana yayılmış olan bir düşmanlığın şekillenmesindeki payı tartışılmazdır. Sorunsala ilişkin medyanın takındığı tavrın kimi durumlarda iktidarın takındığı tavırdan daha önemli olduğu bilinmektedir. Bugün vatandaşlar kendisi yaşayıp görmediği ya da hemen hiç bilgi sahibi olmadığı pek çok konu hakkındaki görüşlerini kitle iletişim araçları ile şekillendirmektedir. Bireylerin zihinsel haritaları televizyon, sinema, radyo, gazete ve dergilerde üretilen amaçlı içeriklere maruz bırakılmak suretiyle inşa edilmektedir. İslamofobinin tüm dünyada giderek yükselmekte olan siyasi bir duruş arz ettiği bilinmektedir. Bu süreçte dünyanın "öteki olarak i̇slam” konusunda ikna edilmesinde Batı ana akım medyası en etkili araç olmuştur. Medyanın kullanımında eşitlik, tarafsızlık ve nesnellik gibi ilkelere karşın var olandan değil gösterilmek istenenden bahsedilmektedir. Bu bağlamda tedavüle sokulan Müslüman imajı üzerinde, nefret duygusunu artırıcı içerikleri yaygınlaştırma kabiliyetine sahip medyanın önemi ortaya çıkmaktadır. Bu çalışmada Fransa'nın yüksek tirajı yayınlarından olan Valeurs Actuelles ve L'Express dergilerinin kapak seçimleri göstergebilimsel analiz yolu ile i̇slamofobi ve medeniyetler çatışması bağlamında ele alınmıştır.

\section{Eylül İkiz Kule Saldırıları Öncesi ve Sonrası Batı Medyasında Müslümanlar}

11 Eylül 2001 tarihinde New York'ta bulunan Dünya Ticaret Merkezine düzenlenen saldırılarda, ABD resmi kaynaklarına göre üç bine yakın insan hayatını kaybetmiştir. Uçaklardan birinin kuleye çarpma ve kulelerin yıkılma görüntülerini tüm dünya canlı yayınla seyretmiştir. Kaçırılan uçaklardan birinin görüntüleri olmamakla beraber ABD Savunma Bakanlığı Pentagon'a çarptı̆̆ı, bir diğerinin ise Washington'u hedef aldığı halde, içindeki yolcuların uğraşları ile Pensilvanya'da düşürüldüğü aynı kaynaklarca dünyaya servis edilen bilgiler arasındadır. Saldırı sonrasında ABD tarafından küresel bir politika olarak Müslüman dünyayı hedef alan propagandalar başlamıştır. Medyada üretilen kampanyalarla i̇slam'la terörizmin, savaşın ya da yoksulluğun yan yana getirilmesi hedeflenirken, diğer yandan Müslüman coğrafyada başlatılan yağmacı ve işgalci hareketlerin meşruiyetine zemin oluşturulmuştur. Abrahamian'a göre (2003, s. 529) bu süreçte ana akım medya 11 Eylül'ü İslam, kültür ve medeniyetler bağlamında medeniyetler çatışmasına başvurarak açıklama yoluna gitmiştir.

Dönemin başkanı George W. Bush'un olayların ardından "haçlı savaşıııı başlatıyoruz" (The Wall Street Journal, 21 Eylül 2001) şeklindeki ifadeleri aynı zamanda İslam dünyasına yönelik bir savaş ilanı olarak okunmaktadır. Ardından yürürlüğe sokulan Vatanseverlik Yasası ile İslamofobinin kanuni bir düzlemde tartışılmasının yolu açılmıştır. İslamofobi medyada Amerikan başkanlık seçimlerinde de sıklıkla kullanılan bir argüman olmuştur. Örneğin Obama'nın ABD başkanlığına aday olmasının ardından ülkede İslamofobi ağının başını çeken Clarion Fund, 70 gazeteciyi aracı kılarak, 28 milyon adet “Obsession” (Radikal İslam'ın Batı ile Savaşı) adlı filmin kopyasının, kararsız eyaletlerde ücretsiz olarak dağııılmasını sağlamıştır. Bu karşıt seçim kampanyasının amacı halkı İslam hakkında korkutmak ve bu korku nedeni ile Obama'ya oy vermelerini engellemektir. Nitekim Barack Obama'nın Müslüman olduğuna yönelik kaygılar başkanlık seçimleri sonrasına değin sürmüştür.' Donald Trump'ın seçim kampanyalarında kullandığı dil de benzer mahiyettedir. Trump “Ülkemizin temsilcileri neler olup bittiğini anlayana kadar ABD'nin kapılarını tüm Müslümanlara tamamen kapatmak istiyorum” diyerek başından beri İslam karşıtı bir duruş sergilemiştir. Öte yandan konuşmalarında artık dünyanın farklı bir tehditle karşı karşıya olduğunu ifade ederken "radikal İslami terör" söylemini kullanmaktadır. Nitekim Irak, Afganistan ve Pakistan'a karşı sürdürülen küresel terörle mücadele ile bu söylemler hayata geçirilmiştir. 
11 Eylül saldırıları sonrasında ABD’nin gerçekleştirdiği fiziki işgaller yanında algı işgalinden de söz etmek mümkündür. Batı medyasında yürütülen enformasyon bombardımanı ile, İslam'ın amaçlı bir fotoğrafı resmedilmeye, Müslüman kimliği ile ilgili mesaj verilmeye çalışılmaktadır. Bu mesaj Müslümanların ve İslam'ın öteki olarak dizayn edilmesi yanında terör ile yan yana getirilmesi talebini içermektedir. Kitle iletişim araçları ise bu süreçte dünyanın düşünce coğrafyasını şekillendirmek için en elverişli araç olmuștur. Bu bağlamda Hollywood film sektörü başta olmak üzere ABD ve Avrupa'nın televizyon, radyo, dergi ve gazeteleri mesajın verilmesi için etkili biçimde kullanılmıștır. Müslüman imajı 11 Eylül saldırıları sonrasında başta ABD olmak üzere tüm Batı medyasını kapsayacak şekilde şiddetle özdeşleştirme aşamasına geçmiştir. Böylece İslam ile terörü, Müslüman ile şiddeti aynı karede işleyen pek çok içerik üretimi ile Müslüman kimliği üzerinde kodlama çalışmaları yapılmaktadır.

Batı'nın düşünce mirasına bakıldığında İslam düşmanlığının yeni bir oluşum olmadığı göze çarpmaktadır. 11 Eylül saldırılarının İslam düşmanlığı üzerindeki etkisi tartışılmazdır ancak Amerika ve Avrupa'da daha evvelinde de İslamofobik eğilimler mevcuttur (Brown, 2000, s. 7). Örneğin 1995 yılında Oklahoma hükümet binasına gerçekleştirilen terör saldırısı sonrası, ABD medyası “islami köktendinci terör” söylemini kullanarak sahte bir algı üretmeye başlamıştır. Katilin yakalanması ile saldırıların Ortadoğu kaynaklı olmadığı anlaşılmışsa da ABD halkının zaten hazırda bekleyen kanaatlerini ve medyanın ürettiği yargıları kırmaya yetmemiştir. Canatan, ırkçı ve İslamofobik eğilimlerin varlığının 11 Eylül saldırılarından bağımsız olduğunu vurgulamaktadır (2007, s. 19). Bu bağlamda İkiz Kule saldırıları İslam ve Müslüman karşıtlığını belirgin hale getirmiş, sosyal ve siyasal hayattaki i̇slamofobik söylem ve eylemlere meşruiyet sağlamıştır. Şu halde ortaçağdan bu yana ABD ve Avrupa'da var olan ve güncelleştirmeyi bekleyen İslamofobi, 11 Eylül saldırılarından sonra kitle iletişim araçlarının desteğini alarak etki nispetini artırmıştır.

Medyanın İslam’ı ele alırken kullandığı dil, kelime öbekleri ya da vurgular amaçlı bir yönelime sahiptir. Bu yönelim olumsuz bir İslam ve Müslüman stereotipi inşa etmeyi amaçlamaktadır. Amerikan medyasında Washington Post ve New York Times gazetelerinde İslam'ın kurgulanmasına yönelik içerik analizi gerçekleştiren bir çalışmaya göre, 10 Ağustos-lo Kasım 2011 tarihleri arasında 247 yayın yapıldığı ifade edilmektedir. Haberlerin çoğunluğunun gazetelerin ilk sayfasında ya da özel başlıklarla verilmiş olması dikkat çekicidir. Haber içerikleri ekseriyetle 11 Eylül terör olayları, Arap Baharı ve İslam' da kadın gibi başlıklara yer vermektedir. Öte yandan istila, barbar, cihat, tehdit, terör, fanatik, hoşgörüsüz ya da gayri medeni gibi mesajların gerek açık gerekse örtülü olarak verilmiş olması, gazetelerin İslam karşıtı içerik üretme konusundaki talebini gözler önüne sermektedir (Göksu ve Saygıll, 2012, s. 96-97). Avrupa medyasında da durum pek farklı değildir. İngiltere menşeli “The Telegraph”, "The Guardian” ve "The Independent” gazetelerindeki haberlerin benzer kodlar içerdiği görülmektedir (Paçacı, 2013, s. 458). Hıdır’a göre Batı medyasında İslam hakkında oluşturulmaya çalışılan imaj "kılıç yolu ile yayılmış, ötekini yok etmeyi hedefleyen, şiddete meyilli, akıldışı bir din olduğuna yöneliktir (2007, s. 85). Batı medyası kendi içinde de bir çelişme içindedir. Pek çok Batı ülkesinde milyonlarca insanın öldürülmesine ve şiddet örneği olmasına karşın, medyanın içerik üretme biçimi çatışmanın yalnızca Müslüman ülkelerde var olduğuna yöneliktir. Örneğin 1995 yılında Oklahoma saldırılarını gerçekleştirenin Timothy Mackey olduğu anlaşılmasına ve saldırganın ideolojik eğilimlerini açıklamasına karşın, kendisi halen Hristiyan terörist olarak değil "yerel terörist" olarak anılmaktadır. Öte yandan medya "yerel teröristleri” psikolojik sorunları olduğu argümanı ile sunma yoluna gitmektedir. Ancak failin Müslüman olduğu durumlarda haberler içeriklerinin din bağlamında üretildiği görülmektedir.

Batı ana akım medyası imal etmek istediği Müslüman tipolojisi için Hollywood film sektörünü de yoğunlukla kullanmaktadır. 1990'lı yılların ilk çeyreğinde ABD filmlerinde Müslüman rolü Arap asıllı olarak karakterize edilmiștir. Bu roller, ekseriyetle zengin Batılı kadınları haremlerine dahil etmek isteyen fırsatçı zengin Arap şeyhleri olarak işlenmiştir. Müslüman karakterlerin geri kalmış, vahşi, medeniyet yoksunu, şehvet düşkünü, fırsatçı ve çok eşli olarak işlendiği dikkat çekmiştir. 1980’li yıllarda ise geri kalmış Müslümanların karşısında ileri bir medeniyet olarak Batılı imajı kendini göstermektedir. Bu bağlamda kılıçla silahın karşıtığında, ileri teknoloji ile Batı'nın türdeşliği vurgulanmaktadır. 1980'li yıllardan sonra ABD’lilerin Arap ülkelerine giderek toplum içindeki kötü unsurlarla savaştığı portreler filmlerde kendine yer bulmuştur. Bu imaj ABD'nin Ortadoğu ülkelerine barıș götürdüğü ve halkın içinde yer alan kötü unsurlarla savaştığına yönelik düşüncenin pekiştirilmesine hizmet etmiştir. 2011 İkiz Kule saldırılarından sonra ise filmlerde İslamofobik eğilimler aleni hale gelmiş, Kur'an-ı Kerim, dua ve Müslüman imgesi ile terör, vahşet ve barbarlık yan yana getirilmiştir. 2006 yapımı “Uçuş-93” filmi 11 Eylül saldırılarında yolcuların müdahalesi ile Pensilvanya'da düşürülen uçağı konu almaktadır. Filmde uçak korsanlarının Kuran okuduğu ya da dua ettiği görüntülere yer verilerek, Müslüman ile suç imgelerini ve kutsal kitap ile terörü yan yana getirmek hedeflenmiştir. Yine 2006 yapımı "Dünya Ticaret Merkezi”, 2007 yapımı "Krallık” ve 2004 yapımı "Çarpışma” isimli filmler İkiz Kule saldırılarından güç alarak 
çekilmiş yapıtlardır. Bu filmlerde mesaj, evrensel değerlere sahip Batıya karşı terör, şiddet düşkünlüğü, yoksulluk, savaş ya ve cehaletle ilişkilendirilen Müslüman dikotomisi ile aktarılmaktadır.²

Said, İran krizinin Kur’an okuyan Müslümanların görüntüsü ile birlikte servis edilmesinin de benzer bir amaca hizmet ettiğini vurgulamaktadır. İslam'ın görsel olarak sınırlanmasının yarattığı tehlikelere işaret eden yazara göre, Batı'nın itici ve olumsuz bir şeyle karşı karşıya olduğu yönündeki düşünceler kuvvetlendirilmektedir (2008, s. 121). Dahası ABD'de yaşayan 14 yaşındaki Müslüman bir çocuğun, evde yaptığı saatin bomba sanılarak gözaltına alınmasına yönelik haberler, durumun vahametini gözler önüne sermektedir (BBC, 2015). Öte yandan imal edilmiş Müslüman imajının üretilmesi için her zaman masum Müslümanların seçilmediği görülmektedir. Kimi zaman da sözde İslam toplumlarından devşirilen müsait örneklerin kullanıldığı bilinmektedir. Bu bağlamda IşiD ve DAEŞ gibi örgütlerin ateşe benzin döktüğü yadsınamaz bir gerçektir. Bu örgütler de kitle iletişim araçlarını kullanmakta ve bir anlamda İslamofobik medya içeriklerinin üretimine katkıda bulunmaktadır.

Batı medyasında İslam düşmanlığını körükleyen yargılı içeriklerin örneklerini çoğaltmak mümkündür. Gazete, dergi, film, TV ya da radyo tarafından üretildiği fark etmeksizin kitle iletişim araçlarının üzerinde uzlaşmış olduğu ortak bir dil dikkat çekmektedir. Buna göre Batı özgürlük, adalet ve eşitlik gibi evrensel değerlerin yegâne temsilcisidir. Buna karşın İslam ve Müslümanlar dünya için bir tehdit oldukları kadar, ilerleme konusunda da isteksizdirler. Dahası bu geri kalmışlık yalnızca Müslümanların tutumundan değil aynı zamanda İslam'ın doğasından kaynaklanmaktadır. Bu bağlamda İslam, ilerlemenin önünde engel bir din olarak servis edilmekte ve geri kalmışlık dini bir kader olarak tasvir edilmektedir. İkiz Kule saldırılarının Batı medyasında sunulan nefret dilini körüklediği bir gerçektir. Ancak 2001 öncesi döneme bakıldığında da i̇slam ve Müslümanlarla ilgili olumlu bir portre çizilmediği görülmektedir. Ikiz kule saldırılarının kitle iletişim araçları için en önemli sonuçlarından biri, en iyi ihtimalle subliminal formda verilen İslamofobik mesajların bilinçli bir gösteriye dönüşmüş olmasıdır. Yardım ve Dalkılıç’a göre ifade özgürlüğü adı altında azınlık gruplara yönelik yıpratıcı, aşağılayıcı, manipülatif ve dışlayıcı haberler yapılmaktadır. Bu bağlamda 11 Eylül Saldırıları sonrası Müslümanlara yönelik islamofobik içerikli nefret söylemin üretilmesinde olduğu kadar yaygınlaştırılmasında da medya ilk sırada zikredilmektedir (2018, s. 98). Günümüz dünyasında iletişime dinamik boyut sağlayan internet gün geçtikçe geometrik olarak artmaya devam eden üye sayısı ile bir kitle iletişim aracına dönüşmektedir. İnternet yalnızca çağdaş insanın geniş, karışık ve anonim bir izleyici kitlesine hızlı bir şekilde kamu mesajlarını iletmek için kullandığı bir teknolojik araç değil, aynı zamanda dünyadaki herkese ulaşma potansiyeline sahip küresel bir ortam yaratmaktadır (Ohiagu, 2011, s. 225). Üye ve abone sayılarının yanında internet, gazete, dergi, televizyon ve radyo kanalları gibi iletişim araçlarında İslamofobik söylemin daha hızlı ve daha geniş bir kitleye ulaşmasına imkân sağlamaktadır. Bu yayın organlarının sosyal medya hesaplarının olması ulaşılan kitle sayısı yanında mesajın hız ve yayılımını arttırıcı özelliğe sahiptir. Örneğin Valuers Actuelles Dergisi'nin 290 Bin, L'Express Dergisi'nin 1.4 Milyon Twitter takipçisi olduğu düşünüldüğünde ulaşılan ve manipüle edilen kitle hakkında fikrimiz belirginleşmektedir. Bilindiği gibi sosyal medya bugün toplumların düşünce yapısının şekillenmesinde ve ideolojilerin yayılmasında yazılı basından daha kuvvetli bir etkiye sahiptir. Bu bağlamda her iki dergi de aynı zamanda sosyal medyanın gücünü kullanmış olmaktadır.

\section{Batı Medyasında Medeniyetler Çatıșması ve İslamofobi}

İslamofobinin etimolojik olarak başlangıcı, Runnymede Trust (1997) isimli ABD dönemsel yayınının Şubat 1991 tarihli sayısını işaret etmektedir. Ardından terim 1997 yılında “Oxford English Dictionary” ye girmiş ve halen yer almaktadır. İslamofobi yabancı korkusunu işaret eden zenofobiye benzemekle beraber, İslam'dan ve Müslüman kimlikten duyulan dehşet, korku ya da endişeye gönderme yapmaktadır (Lorraine, 2006, s. 317).

İslamofobinin imar edilmesindeki temel motivasyon, soğuk savaşın bitmesinin ardından komünizmin yerine İslam'ın ikame edilmesine yönelik arzudur. Bu bağlamda yeni bir öteki ya da düşman arayışındaki Batı, Beyaz Saray'ın Ulusal Güvenlik Konseyi Üyesi Samuel Huntington'ın (2006) Medeniyetler Çatışması tezi ile tanımlanmış düşman talebini pekiştirmiş ve İslam coğrafyası hedef tahtasına oturtulmuştur. Samuel Huntington bu tezi ilk olarak 1993 yılında Foreign Affairs dergisinde yayınladıktan sonra, 1996 yılında Medeniyetler Çatışması ve Dünya Düzeninin Yeniden Kurulması bașlığı ile kitaplaştırmıştır. Teze göre dünya 16. ve 17. yüzyıldan sonra dört ana siyasi evreden geçmiştir. Fransız Devrimine kadar süren ilk aşamada dünyayı güçlü egemenliğe sahip olanlar yönetmiştir. Fransız İhtilali ile birlikte ulus devlet yükselmiş ve birbirine neredeyse eşit olan aktörler, aynı çıkarlar doğrultusunda karar vermiştir. Birinci Dünya Savaşı'nın ardından dünya, komünizm ve faşizmin yükselişine sahne olurken kutupların keskinleştiği bir siyasal düzen hâkim olmuştur. İkinci Dünya Savaşı ile giderek keskinleşen kutuplar, soğuk savaş dönemini beraberinde getirmiştir. Bilindiği gibi Batı Avrupa 
ve Amerika II. Dünya Savaşından sonra komünizmle uzunca yıllar mücadele etmiş, 1990'lı yıllarda komünizm tehlikesi kontrol altına alınmıştır. Soğuk savaş boyunca kendini anti-komünist eksen üzerinden tanımlayan Batı'nın yeni öteki ve yeni düşman arayışı başlamıştır. Huntington'a göre 21. yüzyılda, ideolojiler üzerinden yürütülen çatışmaların yerini medeniyetler arasındaki çatışmalar alacaktır. Dünyayı sekiz medeniyet bölgesine ayıran Huntington, bu medeniyetler arasında ortaya çıkacak çatışmaya dikkat çekmiştir. Bu bağlamda yeni bir dünya savaşı ihtimalinden söz eden yazar, bu savaşın medeniyetler arası bir savaş olacağını vurgulamaktadır. Ancak bu yeni düzen içinde asıl büyük çatışma, Batı ile İslam arasında ortaya çıkacak ve İslam'ın doğasından kaynaklı olacaktır.

Böylece Batı’nın yeni düşman arayışı, komünizm yerine ikame edilen İslam ile sonuçlanmaktadır. Dahası ilerleyen yıllarda öteki Müslüman, kötü Müslümana dönüş(türül)ecektir. Öteki arayışı Batı'nın kendi meşruiyetini var etmesinin ve öteki üzerinden özgürlük ve adalet arayan "biz"in inşa edilmesinin zaruri bir çıktısı mahiyetindedir. Nitekim Batı, kendi özgürlük ve demokrasi anlayışını diğerleri üzerinden tanımlamış ve kendi tanımını üretmiştir. İki kutuplu dünyanın son bulması ile meşruiyet sebebini, diğer bir deyişle ötekini kaybeden Batı, zatına yeniden hayat vermek için İslam'ı bir tehlike olarak tanımlama yoluna gitmiştir. Öte yandan Batı Aydınlanma ile aklı merkeze alarak kutsalın karşısında bir tutum sergilemiş ve dinin bizzat kendisi ile arasına mesafe koyarak seküler değerleri benimsemiştir. Batı'nın evrensel değerlerinin yayılması önünde engel teşkil ettikleri iddia edilen Müslümanların aynı zamanda Avrupa gibi seküler özelliğe sahip Batı toplumlarında bir sorun oluşturdukları da dile getirilmektedir. İslam doğası gereği sosyal bir dindir ve Müslümanlar'ın gerek kılık kıyafet gerekse ibadet talepleri nedeniyle Müslüman görünürlüğü kamusal alanda sorun olarak görülmektedir. Dahası Müslümanlar'ın Batı ülkelerini işgal ederek anayasayı değiştireceğine inananlar da bulunmaktadır. Nitekim Huntington (2006) tezini savunurken İslam'ın sınırlarının kanlı olduğu, baskın bir merkezden yoksun olması nedeniyle istikrarsızlığın kaynağı olduğu, kültürler arası savaşta kaybedenin kültür olacağı ya da kültürün gücü izleyeceği gibi argümanlara başvurmaktadır.

Batı ile İslam arasında yaşanacak çatışmanın kaçınılmaz olacağına yönelik teoriler özellikle Müslüman göçmenlerin yoğun olduğu ülkeler tarafından sahiplenilmiştir. Medeniyetler Çatışması tezinin yanı sıra kitle iletişim araçlarında benzer mahiyetteki konuların tartışmaya açılması, Avrupa ülkelerinde yükselen İslam düşmanlığını körüklemiştir. Huntington'un Batı'yı evrensel değerlerle tanımlaması çatışmayı artırıcı işlev görürken aynı zamanda Müslümanlara yöneltilen saldırıların meşruiyet zeminini oluşturmuştur. 11 Eylül saldırıları ile yaygınlık kazanmışsa da İslamofobinin yükselişi 1980'li yıllara tekabül etmektedir. Buna mukabil İran İslam Devrimi, Tahran Rehine Krizi ve Körfez Savaşı gibi olgular, 11 Eylül saldırılarından evvel ABD ve Avrupa'da İslam karşıtlığının yükselmesine hizmet etmiştir. Daha yakın tarihte gerçekleşen Belçika ve Paris saldırıları, İstanbul'da Sinagog ve İngiliz Bankasında gerçekleştirilen eylemler, Madrid ve Londra'daki metro saldırılarının da İslam düşmanlığının körüklenmesindeki payı tartışılmazdır. Daha evvel siyasetçiler tarafından sürdürülen İslamofobi kampanyaları 11 Eylül Saldırıları ile beraber halk katına inmiş ve olumsuz İslam düşüncesi iyice gün yüzüne çıkmıştır. Öte yandan muhafazakâr ve aşırı sağcı partilerin göçmen düşmanlığı üzerinden yürüttüğü popülist söylemler de halk nazarındaki nefret suçlarının artışı üzerinde etkilidir. Nitekim Batı Avrupa ve Kuzey Amerika 1990'ların sonundan itibaren krize girmiş, ekonomi bozulmuş ve işsizlik artmıştır. Bu aşamada bozulan ekonomi ve artan işsizlik oranları için Müslüman göçmenler günah keçisi olarak belirlenmiştir. Böylece Batı'da zaten var olan İslamofobik tutumlar gündelik hayatın bir parçası haline gelmiştir. Müslüman göçmenler her geçen gün etki nispeti artan dışlayıcı ve ayrıştırıcı bir üsluba maruz kalmaktadır.

İslam merkezlerine yönelik saldırılar, cami kundaklamaları, cami yapımlarına konulan ambargolar, Müslümanlar’a uygulanan vize sınırlandırmaları, iş hayatında uygulanan ayrımcılık, sözlü ve fiziki saldırıların yanı sıra Müslümanlar'ın potansiyel terörist olarak gözetim altında tutulması İslamofobinin emarelerinden yalnızca bir kısmıdır. İslamofobiden kaynaklı şiddet üretimleri görünür ya da görünmez olarak pek çok biçimde ortaya çıkmaktadır. Nitekim Müslümanların en iyi ihtimalle küçümsendiği, alay edildiği, görmezden gelindiği ya da küçümsendiği dikkat çekmektedir. Özellikle Batı'da ana akım medyanın kullandığı ötekileştirici dil, nefret suçlarını artırdığı kadar Müslümanlar'a yöneltilen saldırıları normalleştirmiştir. Müslüman evlerinin hedef gösterilmesi, öğrencilere uygulanan tacizler ya da Hindistanlı bir kadının başörtüsü taktığı için Müslüman sanılarak öldürülmesi gibi pek çok örnek üzerinden Müslüman nefretini ifade etmek mümkündür. İslamofobi her zaman bir cami kundaklaması kadar görünür olmayabilmektedir. Şu halde İslamofobinin psikolojik görünümlerinin ispat edilmesi, fiziki şiddet kadar talihli değildir.

1990'lı yıllardan itibaren ABD’nin yanı sıra Almanya, İngiltere, Hollanda, İspanya ve Fransa gibi kıta Avrupa ülkelerinde Müslümanlar’a yönelik şiddetin her geçen gün arttığı kaydedilmektedir. 11 Eylül saldırılarının 
İslamofobinin yayılımı bakımından bir miat olduğunu kabul etmek gerekmektedir. Ancak medeniyetler çatışması Huntington'un vurguladığı gibi İslam'ın doğasından değil, Batı'nın doğasından kaynaklanmaktadır. Batı dünyasının "biz" ve "öteki” olarak inşa ettiği dışlamacı dünya algısı mütemadiyen düşman üretmekte ve diğerlerinin reddi yoluna gitmektedir. Nitekim ABD ve Batı'da ayrımcılı̆ıın kökenini çok daha eskilere dayandırmak mümkündür. Kızılderililer, Siyahiler, komünistler, Meksikalılar, Yahudiler ve bugün Müslümanlara yöneltilen ötekileştirici yaklaşım düşünüldüğünde asıl sorunun Batı'nın tutumundan kaynaklandığı düşünülmektedir.

\section{Valeurs Actuelles ve L'Express'de Medeniyetler Çatışması ve i̇slamofobi}

\section{Yöntem}

Batı ana akım medyasının Müslümanlara yönelik önyargı ve kalıp yargıya dayalı yayınlarının, i̇slam medeniyeti ve Batı medeniyetini karşı karşıya getirerek İslamofobinin artmasına katkıda bulunduğu tartışılmazdır. Avrupa medyası 11 Eylül ikiz Kule saldıııları öncesi olduğu gibi sonrasında da Müslümanları hedef tahtasına oturtarak Batı değerleri ile uyumlarını sorgulamaktadır. Oryantalist perspektif doğrultusunda Batı medyasının İslam ve Müslümanlara yaklaşımı dışlayıcı ve ötekileştirici özelliğe sahiptir. Bu bağlamda saldırılardan 10 yıl sonra Fransa'nın yüksek tirajı yayınları arasında yer alan Valeurs Actuelles ve L'Express dergilerinin Ekim sayılarının göstergebilimsel analizinden yola çıkılarak İslamofobi ve medeniyetler çatışmasının ilişkisi analiz edilmiştir.

Göstergebilimin kurucularından olan Saussure, göstergebilimi dil bağlamında ele almıştır. Buna göre dil sembolleri, sözcükleri ya da birbirinden ayrı anlam katmanlarını içeren bir göstergeler dizesidir. Saussure' a göre gösterge gösteren ile gösterilenden oluşmakta ve ikisi arasındaki ilişkiye dayanmaktadır. Gösteren bir resim, görüntü ya da nesne olabilir ancak gösterilen, nesnenin somut varlığından ziyade göstergenin zihinde beliren soyut ya da kavramsal boyutuna gönderme yapmaktadır (Saussure, 1998). Saussure'ün modelini popüler kültür, fotoğraf ve reklamlara uyarlayarak genişleten Barthes (1993) göstergelerin farklı kültürlerde farklı anlamlar üretebileceğine dikkatimizi çekmektedir. Nitekim toplumların kültürleri, değer yargıları ya da inançları göstergelerin üretim kabiliyetini etkilemektedir. Saussure'ün göstergebilim yaklaşımına düzanlam ve yananlam kavramlarını ekleyen Barthes'a göre kendisinden başka bir şey karşıık gelen gösterge hem düz hem de yan anlama sahiptir. Bu anlam ne söylendiği ve nasıl söylendiği ile yakından ilgilidir. Düz anlam göstergenin ne söylediğine işaret ederken yan anlam o şeyin nasıl söylendiğine dikkat çekmektedir. Bu bağlamda düz ve yan anlamların bir araya gelmesi ile göstergeler mit denilen yeni anlamları ortaya çıkarmaktadır. Barthes'a göre (1991) mitler yazılı, sözlü ya da görsel mahiyette olabilirler ancak önemli olan mitlerin amaçlı bir yönelime sahip olması ve alıııda istenen duyguyu ortaya çıkarmak için tasarlanmasıdır. Tıpkı göstergeler gibi mitler de anlamlarını üretirken içinde belirdikleri toplumun kültürel bağlamından etkilenmekte ve popüler kültür tarafından üretilmektedir. Şu halde bir miti ele alırken ideoloji ya da figürün amacı ve üretmek istediği anlamın yanı sıra bu ideoloji ya da figürün popüler kültürde neyi temsil ettiği son derece önemlidir. Öte yandan bir mitin inşa edilmesindeki asıl amaç o toplumdaki hâkim anlayışın ideolojisini doğal hale getirmektir.

Bu çalışmada Valeurs Actuelles ve L'Express dergilerinin önemli gösterge ve kodlarının temel söylemlere nasıl anlam kazandırdığı analiz edilerek belirlenmeye çalışılmıştır. Böylelikle medyanın göstergeleri dönüştürmek sureti ile yeni mitler ürettiği üzerinde durulmakta ve Batı toplumunun kültürel değerleri doğrultusunda İslam'ın bir figür ya da ideoloji olarak neyi temsil ettiği analiz edilmektedir. 
Journal of Media and Religion Studies

\section{Valeurs Actuelles ve L’Express Dergileri Örneği}

Resim 1. Valeurs Actuelles, Ekim 2011 Sayısı: İslam, Fransa ve Avrupa’yı Nasıl Değiștirecek / Dönüştürecek?

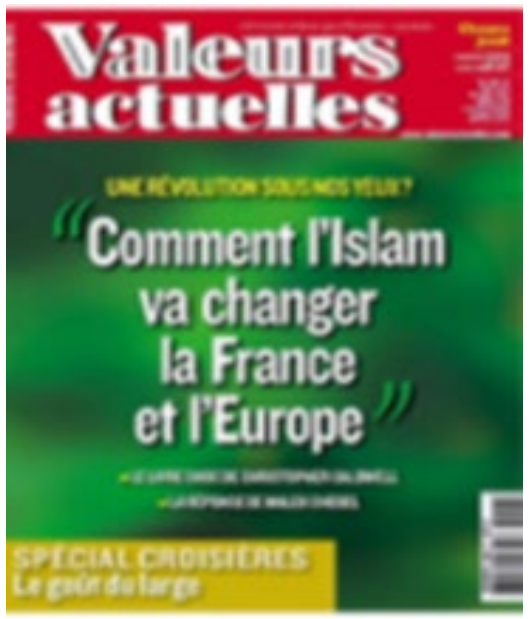

Resim 2. . L’Express, Ekim 2011 Sayısı: Batı İslam’a Karşı

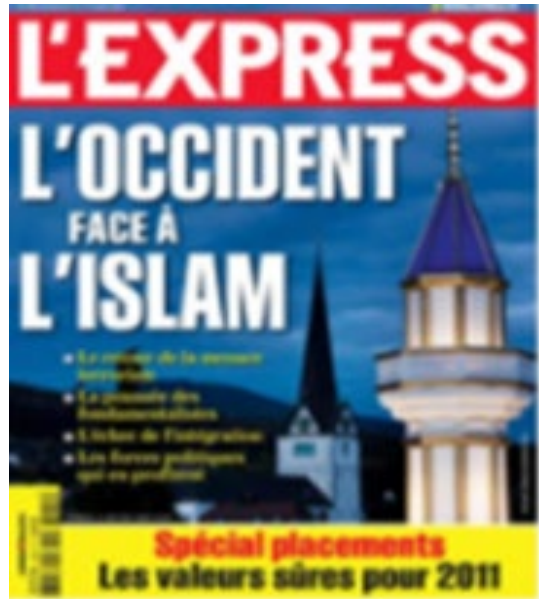

Son yıllarda Batı medyasında Avrupalı Müslümanlar medeniyetler çatışması çerçevesinde haber yapılmaktadır. Valeurs Actuelles ve L'Express dergilerinin Ekim 2011 tarihli sayıları da Fransa ve Avrupa'da Müslümanlar ve dolayısıyla İslam'ı ele almaktadır. Valeurs Actuelles'in sayısının arka fonunda İslam'ı sembolize eden yeşil renk dikkat çekmektedir. L'Express'in sayı kapağında ise gökyüzünü sembolize eden mavi arka fon üzerine önde ve daha görkemli cami minaresi ile arkada ve biraz silik kalan kilise çan kulesi görülmektedir. İslam ve Batı büyük karakterle yazılmışken diğer kelimeler daha küçük karakterlerle başlıkta yerlerini almaktadır. Her iki kapakta da İslam ve ona bağlı değerler daha ön plana çıkartılmaktadır. Böylelikle her iki örnekte de İslam’a hem kavram olarak hem de görsel olarak vurgu yapıldığı görülmektedir. Bu vurgu daha çok bir korku unsuru olma özelliğini taşımaktadır. Ayrıca her iki örnekte arka fonda kullanılan renkler de dikkat çekmektedir. Renklerin, psikolojik etkileri olduğu kadar sembolik anlamlar da taşıdığı düşüncesinden yola çıkıldığında yapılan haberlerin ideolojik bir anlam taşıdığı anlaşılmaktadır.

Kapak sayfalarında “íslam, Fransa ve Avrupa’yı nasıl değiştirecek/ dönüştürecek?” ve “Batı, İslam'a karşı” şeklindeki başlıklarla bir din olan İslam'ın karşısına Fransa ve Avrupa coğrafi olarak konumlandırılmaktadır. Özellikle medya tarafından son yıllarda bilinçli şekilde din ile coğrafi bölgenin karşı karşıya getirilmesi sıkça başvurulan bir yöntemdir. Bu örnekler “islam ve Avrupa” veya “íslam ve Batı" konularını ele alırken İslam ile Avrupa'nın dini ve kültürel mirasının temelini oluşturan Hristiyanlığa vurgu yapmaktadır. Tartışma medyanın belirlediği kavramlar üzerinden sürdürülmektedir. Stuart Hall’in (1974, s. 18-21) ifadesiyle “kitle iletişim araçları, kamuoyunu ilgilendiren sorun ve konuların tanımlanmasında çok önemli bir rol oynamaktadır. Sorunların "merkezi" veya marjinal olarak tanımlandığı terimleri belirlemektedir". Aslında medyanın tanımladığı ve biçimlendirdiği kavramlar, bir tarafta İslam medeniyeti diğer tarafta ise Hristiyan kökenli Avrupa medeniyeti 
olarak tarihten bu yana çatışma halinde olan ve birbirinden her boyutuyla farklı iki dünya kurgulamaktadır. Batı'nın İslam ve Müslümanlara düşmanca yaklaşımının tarihçesi oldukça eskiye dayanmaktadır. Oryantalizm tarihi, Doğu-Batı/ İslam-Hristiyanlık arasında kurgulanan polarizasyonunu yansıtmaktadır. Bir başka ifadeyle her birinin kendine özgü özellikleri, kimliğ̈i, düşünme ve dünyayı görme biçimleri ve tarihleri bulunan ve birbirinin zıddı olarak sunulan iki farklı dünya, iki farklı medeniyet tasavvur edilmektedir. Oryantalist düşüncenin Doğu-Batı ayrımında Müslüman Doğu medeniyeti katı, zalim, hoşgörüsüz, irrasyonel ve medeniyet seviyesine ulaşamayan şeklinde tasvir edilirken, Batı gibi gelişmediği ve geri kaldığı gerekçesi ile ötekileştirilmiştir. İslami değerler ve Müslümanlar Hristiyan Batı literatüründe "düşman" ve "tehdit" olarak nitelendirilmişlerdir. Nitekim o dönemlerde İslam ve Müslümanlar "dışarıdaki düşman”" ve "dışarıdaki öteki” olarak görülmekteydi.

Batı medyasının, i̇slam ve Müslümanları ele alırken gerçeklerden çok hayali bir kurgu olan "ben ve öteki" ve "biz ve onlar" ayrımına sıkça başvurduğu görülmektedir. Edward Said, Covering Islam (1981, s. 169) başııkı çalışmasında Batı medyasının İslam ve Müslümanları haber yapma noktasında oldukça etkili ve başarılı olduğunu vurgularken bu başarının, gerçekliğe veya kesinliğe dayanmadığını, sadece onu üreten kişi ve kurumların siyasi etkisine bağlı olduğunu savunmaktadır. Ötekileștirme süreci ırk ve din üzerinden yapılmaktadır. Saeed (2007, s. 443-449) Müslümanların medyada "yabancı bir öteki”" olarak tasvir edildiğini ve bu yanlış beyanın, "ırkçııık” ın, dolayısı ile "öteki”nin kültürel temsillerinde bulunan İslamofobinin gelişimiyle bağlantılı olabileceğini öne sürmektedir. Hem dini hem de kültürel anlamda Hristiyan Batı' dan farklı olan Müslümanlar için Batı'nın sınırları dışında, Doğu'da, yaşayan bir düşman tanımı yapılmaktaydı. Ancak 20. yüzyıldan itibaren tarihi düşmanın statüsü değişime uğramıştır.

Asırlar önce şekillendirilen Müslüman Doğu ile Hristiyan Batı arasındaki uçurum bugün de tazeliğini korumaya devam etmektedir. Son zamanlarda daha da alevlenen Avrupa'daki göçmen tartışması Müslüman ve İslam'a odaklanmaktadır. Batı'nın sömürge altına aldığı ülkelerden gelen ve özellikle 20. yüzyılda Türkiye gibi ülkelerden Avrupa'ya göç dalgası ile dışarıdaki düşman Batı'nın topraklarına yerleşmiş ve iç düşmana dönüşmüştür. Valeurs Actuelles ve L'Express dergi kapakları da tarihten gelen düşmanlığın bugüne yansımasını tartışmaya açmaktadır. Görseller ve başlıklarda "içimizdeki düşman medeniyetimizi tehdit ediyor" mesajı verilirken İslam ve Müslümanların Avrupa'da varlıkları tartışma konusu yapılmaktadır. İslam ve Müslümanlar Avrupa'nın sosyokültürel ve sosyopolitik peyzajında yer alsalar da farklııılarından dolayı dini ve kültürel kimliğe tehdit olarak algılanmakta ve ötekileştirilmektedir.

Bu bağlamda Valeurs Actuelles ve L'Express dergileri Ekim 2011 sayıları Samuel Huntington'un yıllar önce savunduğu Medeniyetler Çatışması (1993) tezini hatırlatmaktadır. Sovyetler Birliğinin sona ermesiyle birlikte kadim düşman yaklaşımı medeniyetler çatışması ile alevlenmiştir. Huntington'un medeniyetler çatışması tezine göre Soğuk Savaş’tan sonra çatışmalar ekonomik ya da ideolojik nedenlerle değil kimlik ve kültür eksenli olacaktır. Daha açık bir ifadeyle çatışma medeniyetler arasında kurgulanmaktadır. Huntington çalışmasında İslam medeniyetinin, en üstün medeniyet olarak değerlendirdiği Batı medeniyeti için bir tehdit oluşturduğu düşüncesini savunmaktadır.

1990'lı yıllarda gündeme gelen Medeniyetler Çatışması teorisine vurgunun 11 Eylül saldırılarından sonra arttığı gözlemlenmiştir. Özellikle 11 Eylül ikiz Kule saldırıları sonrası Müslümanların tehdit, düşman ve terörist olarak algılanması ivme kazanmıştır. Medeniyetler arasında bir çatışma çerçevesinde değerlendirildiğinde saldırıların, Müslümanların Batı değerlerine açtıkları bir "savaş" olduğu düşüncesi şaşırtıcı değildir. Bir başka ifadeyle zulüm, zorbalık ve terörü temsil eden barbarların (Müslümanların) demokrasi, insan hakları ve hukukun üstünlüğü için mücadele eden medeniyete (Batı) karşı savaşı sembolize edilmektedir. Batı'nın çatışma algısında Müslümanlar, savaşılması gereken birer terörist olarak değerlendirilmektedir. Sadece akademide değil medya ve siyasi arenada da benzer söylemler ortaya çıkmaktadır. Manuel Valls ve Nicolas Sarkozy'nin 2015 tarihinde kullandıkları "medeniyetler savaşı" kavramı Emmanuel Macron tarafından El-Mundo (27 Aralık 2017) gazetesine verdiği bir röportajda kullanılmıştır. Medeniyetler çatışması, kimliklerin manipüle edilmesinde önemli politik bir rol oynamaya devam etmektedir. Bu yaklaşım, çatışmaları tüm karmaşıklıkları içinde kavramak yerine, tanımlanmış okuma biçimlerine göre yorumlamayı mümkün kılar. Ancak oryantalist düşünür Bernard Lewis de benzer görüşleri paylaşmaktadır. Ona (1990) bu çatışma eski rakip olan İslam medeniyetinin Batı'nın Musevi-Hıristiyan mirasına, mevcut laikliğine ve her ikisinin de küresel genişlemesine karşı tarihsel bir tepkidir. Valeurs Actuelles ve L'Express dergi kapaklarında da Fransız siyasetçiler veya oryantalizmin önde gelen isimlerinden Lewis örneğinde olduğu gibi İslam medeniyetinin, Batı medeniyetini tehdit eden homojen ve totaliter bir ideoloji olduğu yaklaşımı ön plana çıkmaktadır.

Dergi kapaklarında öne çıkan diğer bir nokta Batı'da İslam'ın daha baskın hale gelerek Batı'yı dönüştüreceği ve Batılı değerleri değiştireceğidir. Bu bağlamda Müslüman görünürlüğü, nüfus sorunu olarak görül- 
mektedir. Müslümanların çoğalarak yayıldıkları ve bir müddet sonra Batı toplumlarında hakimiyetlerini ilan edecekleri korkusu dillendirilmektedir. Bu düşünce Valeurs Actuelles dergisinin kapak başlığında ve L'Express dergisinde cami ve kiliseyi bir araya getiren görselde ortaya çıkmaktadır. Bu söylem daha çok aşırı sağ tarafından dile getirilse de medyanın kayıtsız kalmadığı görülmektedir. Causeur dergisinin Eylül 2021 sayısı, Avrupalı nüfusun hızı bir artış gösteren Müslüman nüfusu karşısında azınlık konumuna düșeceğini iddia etmektedir. Görsel olarak esmer renkli bebeklerin beyaz renkli bebeklerin önüne geçtiği dikkat çekmektedir. Azınlıkta olan Müslüman göçmen çocuklarının birkaç sene sonra çoğunlukta olacakları, aynı şekilde çoğunlukta olan Avrupalıların azınlıkta kalacakları vurgulanmaktadır. Böylelikle çoğunlukta olan Müslümanların Avrupa'nın toplumsal, siyasal, kültürel ve dini yapısını değiştireceği iddia edilmektedir.

\section{Sonuç}

Müslümanların Batı medyasındaki temsilleri önyargı ve kalıp yargılara dayalı yayınlarla aşağılama, küçümseme, dışlama ve ötekileştirme etrafında şekillenmektedir. Böylelikle Müslümanlar temsil sorunu yaşamakla beraber Batı medeniyeti ile sürekli çatışma halinde olduklarına dair algı kurbanı olmaktadır. İslam medeniyetinin Batı tarafından dini ve kültürel kimlik kaynaklı ötekileştirilmesi yeni bir olgu değildir. Tarihsel sürece bakıldığında İslam ve Müslümanların barbar, zalim ya da medeniyet yoksunu gibi olumsuz nitelemelere maruz kaldıkları görülmektedir. 21. yüzyılda da durumun farklı olduğunu söylemek oldukça zordur. Tarihsel süreçte tekrarlanan bütün önyargı ve kalıp yargılar dün olduğu gibi bugün de medya tarafından kullanılmaktadır. Bu bağlamda İslam ve Müslümanların bir düşman olarak işaret edildiği dikkat çekmektedir.

Valeurs Actuelles gibi L'Express dergisi de kullandığı görsel ve başılılarla tarihten gelen bu düșmanlığı hatırlatmaktadır. Dünyayı İslam ve Avrupa olarak iki blok halinde kurgulayan dergiler, tarihi düşmanın tehdidine dikkat çekmektedirler. Özellikle Haçlı Seferleri ile daha belirgin hale gelen Müslümanların düşman olarak görülmeleri sonraki dönemlerde de çeşitli yapıtlarla ortaya konmuştur. 21. yüzyılda dergilerin İslam ve Müslümanları "eski düşman" olarak ele alışlarında da devamlıık söz konusudur. Dergi kapaklarında İslam ve Müslümanlar tarihi eskilere dayanan düşman ve öteki perspektifinden okuyucuya sunulmaktadır. Bu bağlamda bir tarafta bütün olumsuzlukları, şiddet ve barbarlığı simgeleyen İslam medeniyeti, diğer tarafta kendini medeniyetin sembolü olarak tanımlayan Batı medeniyetinin çatışması gündeme getirilmektedir. Valeurs Actuelles ve L'Express dergileri kullandıkları görsel ve başılılarda tarihte dış düşman olarak algılanan Müslümanların iç düşman olarak ülkelerini tehdit ettiklerini savunmaktadır. Ayrıca çatışan iki medeniyet tasavvurunda i̇slam medeniyetinin Batı medeniyetini zayıflatarak varlığını zora sokacağı ifade edilmektedir. Bir başka ifadeyle İslam medeniyeti tarafından tehdit edilen Batı medeniyetinin her açıdan zayıflama sürecine girdiği vurgulanmaktadır. Bu zayıflama ile beraber ilerleyen dönemde İslam medeniyetinin Avrupa'da egemenliği ele geçirerek çoğunluğu oluşturacağı iddia edilmektedir. Müslümanların Batı medyasındaki temsili, olumsuz unsurlara dayanmaya devam ettikçe, Batı toplumlarında bir “öteki” ve bir "düşman” olarak görülmeye devam edilmesi kaçınılmazdır.

\section{Son Notlar}

${ }^{1}$ TRT İslamofobi Belgeseli (2008). 4. Bölüm'den yararlanılmıştır.

21991 ABD Yapımı "Kızım Olmadan Asla”, 1991 ABD yapımı "Şeyh”, 1942 ABD yapımı "Arap Geceleri”, 1944 ABD yapımı "Ali Baba ve Kırk Haramiler" ve 1947 ABD yapımı "Denizci Sinbad" bu filmlere örnek olarak verilebilir.

\section{Kaynakça}

Abrahamian, E. (2003). The US media, Huntington and September 11. Third World Quarterly, 24(3) 529-544.

BBC. (22 Eylül2015). Yaptığı saat bomba sanılan Ahmet Muhammed'e Google'dan jest. https://www.bbc.com/ turkce/haberler/2015/09/150922_ahmed_muhammed_google

Barthes, R. (1993). Göstergebilimsel serüven. Çev. Mehmet Rifat, Sema Rifat, İstanbul: Yapı Kredi Yayınları.

Barthes, R. (1991). Mythologies. Çev. Annette Lavers, New York: The Noonday Press.

Brown, M. D. (2000) Comparative perspectives on racism. Ed. Jessika Ter Wal ve Maykel Verkuyten. Aldershot: Ashgate Publishing.

Canatan, K. (2007). İslamofobi ve Anti-i̇slamizm - kavramsal ve tarihsel yaklaşım. Batı dünyasında İslamofobi ve Anti-isslamizm İçinde. Ed. Kadir Canatan ve Özcan Hıdır. Ankara: Eskiyeni Yayınları. 
Göksu, V. ve Saygıılı, R. (2012). Amerikan medyasının İslam algısı. İslamofobi Kolektif Bir Korkunun Anatomisi Sempozyumu. Ed. Osman Alacahan ve Betül Duman. Sivas: İbn-i Hüman Vakfı Yayınları.

Hall, S. (1974). Black men, white media. Journal of the Caribbean Artists Movement, 9(10), 18-21.

Hıdır, Ö. (2007). Anti-Semitizm ve Anti-islamizim: Benzerlikler ve farklılıklar. Batı dünyasında İslamofobi ve Anti-islamizm İçinde. Ed. Kadir Canatan ve Özcan Hıdır. Ankara: Eskiyeni Yayınları.

Huntington, S. (2006). Medeniyetler çatışması ve yeni dünya düzeninin yeniden kurulması. çev. Mehmet Turhan, Cem Soydemir. İstanbul: Okyanus Yayınları.

Lewis, B. (1990). The roots of Muslim rage. The Atlantic Monthly, 47-60.

Lorraine P. S. (2006). Islamophobia pre-and post-september 11th, 2001. Journal of Interpersonal Violence, 21(3), 317-336.

Ohiagu, O. (2011) The internet: The medium of the mass media. Kiabara Journal of Humanities, 16(2), 225-232.

Paçacı, M. (2013) İslamofobi. Kutlu Doğum Haftası Hz. Peygamber ve Insan Onuru Sempozyumu. Ankara: Diyanet İşleri Başkanlığı Yayınları.

Saeed, A. (2007). Media, racism and Islamophobia: The representation of Islam and Muslims in the media. Sociology Compass, 1(2), 443-462.

Said, E. W. (1981). Covering Islam: How the media and the experts determine how we see the rest of the world. New York: Pantheon Books.

Said, E. W. (2008). Medyada i̇slam. İstanbul: Metis Yayıncllık, İstanbul.

Saussure, F. (1998). Genel dilbilim dersleri. Çev. Berke Vardar, İstanbul: Multilingual Yayınları.

The Runnymede Trust. (1997). İslamophobia. A Challenge For Us All.

The Wall Street Journal, 21 Eylül 2001.

Yardım, M. ve Dalkıııç, M. (2018). Nefret söylemi ve ifade özgürlüğü tartışmaları çerçevesinde İslamofobya: L’Express dergisi örneği. Medya ve Din Araştırmaları Dergisi (MEDIAD), 1(1), 89-109. 


\title{
MEDIAD
}

\section{The Conflict of Civilizations and the Perception of Islam in Valeurs Actuelles and L'Express after 11 September}

\author{
Müșerref YARDIM \\ Betül KARAKOYUNLU
}

Extended Abstract

The September 11 Twin Tower attacks are of vital importance in terms of Islamophobia in the West and therefore the perception of Muslims living in Western countries. From this date on, a visible momentum in the opposition to Islam and Muslims has not gone unnoticed. Blaming Muslims for the September 11 attacks has created a negative and hostile atmosphere such as physical and psychological violence, discrimination, exclusion and marginalization. These attacks targeted Islam in the context of culture and civilization, and Muslims were treated as potential terrorists. Immediately after the attacks, a call for war based on religion and civilization was developed using a confrontational language. The official discourse since the then-president of the state, George W. Bush, has been based on the fact that Muslims are an enemy to be fought. A clash based on culture and civilization expressed by the media, intelligentsia and politicians overlaps with the Clash of Civilizations thesis written by Samuel Huntington. Expressing that the conflicts will be based on culture and civilization, Huntington exhibits an orientalist approach to Islam and Muslims. From this point of view, it is argued that the September 11 attacks are a conflict between Western civilization and Islamic civilization.

In the representation of Muslims in the Western media, the September 11 attacks are cited as a turning point. The role of the mass media in creating a negative image about Muslims is indisputable, with the disinformation, intense campaigns and propaganda they carry out. The view in the media that Muslims were prone to violence, which existed before 9/11, was put forward in clearer terms after the attacks. Especially cinema, television, radio, magazines and newspapers should be mentioned in the first place in the formation of the perception that Muslims are terrorists. Western media has tended to feed the clash of civilizations with representations based on prejudices. It is seen that the reactions to the September 11 attacks and the stigmatization of Muslims as terrorists because of their beliefs have become a routine, giving legitimacy to islamophobic hate speech and hate crimes.

Although many years have passed since the September 11 attacks, the idea of a clash of civilizations in the Western media is still current today. 10 years after the September 11 attacks, Valeurs Actuelles and L'Express magazines published publications presenting Islamic civilization and Western civilization in conflict. The background, such as the green color used on the covers of Valeurs Actuelles and L'Express magazines, visuals such as churches and mosques, and "How will Islam change / transform France and Europe?" and "West against Islam" emphasize the East-West distinction that orientalism has been expressing for centuries. Prejudice, stereotypes, and intolerant and hostile attitudes towards Islam and Muslims began to emerge with the emergence of Islam. Throughout history, the Christian West has marginalized the Muslim East with different methods. Two opposite worlds, positive and negative, are perceived by orientalism. In Valeurs Actuelles and L'Express magazines, Islam and Muslims are mentioned not only as the opposite pole of the West, but also as the "external enemy" that turns into an "internal enemy". Islam and Muslims are perceived as an "internal threat" that does not belong to Western lands, does not comply with Western values, even conflicts and fights. This discourse turns Muslims into an "undesirable" minority group in the Western lands.

By placing geographical regions such as Europe or France on the covers of the magazines, the emphasis is on Christianity. In the media's construction of the Self and the Other, the "imaginary Eastern Muslim" Other is made. The media not only creates an unrealistic image of Muslims, but also turns Islam and Muslims into fear. The existence of Muslims, who are perceived as a danger and a threat, in Western societies is ques- 
tioned. This fear is based on the idea that Muslims will soon dominate Western societies by gaining a majority in numbers. When we go into a little more detail, it is seen that the fertility rates of Muslims, especially the spread of Islamic names such as Muhammad by giving children in Western societies, the visibility of Muslims in the public sphere and the demands for freedom of religion and conscience are met with concern. In addition to different segments of the society, especially the media draws attention in the formation of the fear that those in the minority will become the majority and impose their own order. This situation is also evaluated as the weakening and disappearance of Western values based on the Judeo-Christian tradition in the face of Islamic values. In the images used on the covers, this idea emerges with the mosque minaret, which is presented more magnificently opposite the church bell tower. It is stated that just as the minaret dominates the church bell, Muslims will also dominate over the Westerners.

\section{Araştırmacıların Katkı Oranı Beyanı/ Contribution of Authors}

Yazarların çalışmadaki katkı oranları eşittir.

The authors' contribution rates in the study are equal.

$* * * * * * * *$

\section{Çıkar Çatışması Beyanı / Conflict of Interest}

Çalışma kapsamında herhangi bir kurum veya kişi ile çıkar çatışması bulunmamaktadır.

There is no conflict of interest with any institution or person within the scope of the study.

$* * * * * * * *$

\section{Intihal Politikası Beyanı / Plagiarism Policy}

Bu makale iThenticate yazılımıyla taranmıştır. Intihal tespit edilmemiştir.

This article has been scanned by iThenticate. No plagiarism was detected.

$* * * * * * * *$

Bilimsel Araştırma ve Yayın Etiği Beyanı / Scientific Research and Publication Ethics Statement

Bu çalıșmada “Yükseköğretim Kurumları Bilimsel Araştırma ve Yayın Etiği Yönergesi” kapsamında uyulması belirtilen kurallara uyulmuştur.

In this study, the rules stated in the "Higher Education Institutions Scientific Research and Publication Ethics Directive" were followed. 